\title{
Synthesis of new 1,2 dithiol 3-thione fluoroquinolone esters possessing anticancer activity in-vitro
}

\author{
B.B. Saeed ${ }^{1}$, M.A. Al-Iraqi ${ }^{1}$ and F.T. Abachi ${ }^{*}$ \\ ${ }^{1}$ Department of Chemistry, College of Science, ${ }^{2}$ Department of Pharmaceutical Science, College of Pharmacy, University of \\ Mosul, Mosul, Iraq, * corresponding author
}

\begin{abstract}
Three 1,2 dithiole 3-thion fluoroquinolone esters (2-4) were prepared via condensation of ( $p$-hydroxyl phenyl) -1,2dithiole3 -thione with fluoroquinolones (Ciprofloxacin, Gatefloxacin and Moxifloxacin). The biological activity of these compounds was assayed against 60 types of cancer cells in vitro. The compound $2(\mathrm{NSC}=760553)$ showed anticancer activity against renal cell, while the comound 4 ( $\mathrm{NSC}=760555)$ show activity against three types of cancer cell. The expected mechanism of their activity is that 1,2dithiole 3-thione derivatives may give $\mathrm{H}_{2} \mathrm{~S}$ as new gas transmitter which play an important role in the biological systems.
\end{abstract}

Keywords: Fluoroquinolone; Anticancer; Ciprofloxacin; Gatefloxacin; Moxifloxacin Available online at http://www.vetmedmosul.org/ijvs

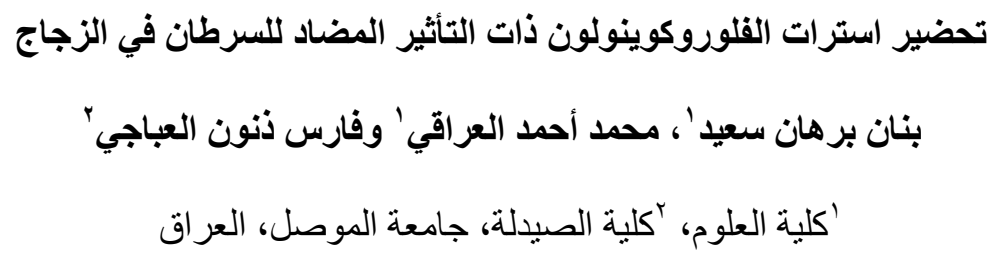

الخلاصة

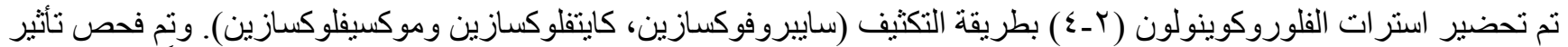

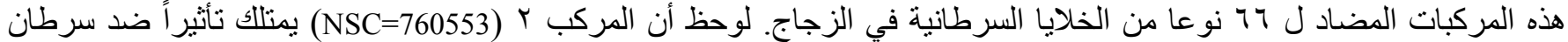

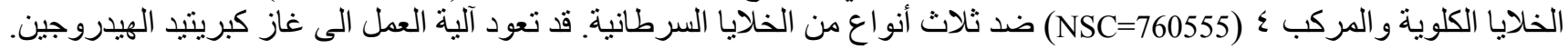

\section{Introduction}

Dithiolethiones I (1,2 dithiole-3-thiones) and its derivatives have anti cancer activity (1). Oltipraz and related dithiolethione derivatives are an important class of chemopreventive agents that enhance the expression of carcinogen detoxication and antioxidant agents (2). Since, many synthetic compounds have been used to protect animals against a variety of cancer (3). Hydrogen sulfide has been shown to be a potent endogenous gasous mediator in many physiological and pathological processes. Hydrogen sulfide $\left(\mathrm{H}_{2} \mathrm{~S}\right)^{4}$ in mammalian tissues is produced from L- cysteine, the sulfhydryl group (SH) be the essential species which responsible for the biological activities of these compounds. Dithiolethione derivatives expected to release sulfhydrl group (SH) seems to contribute to the pathogenesis of several diseas, including Alzheimer disease, hypertension and other diseases $(3,4)$.<smiles>Cc1c(-c2cnccn2)ssc1=S</smiles>

Oltipraz 
Dithiolthiones (1,2 dithiol-3-thione) derivatives are a family of promising cancer chemoprotective agents (2). Fluoroquinolones ability to inhibit the activity of DNA grase and topoisomerase IV and promise to have dual acting as antibacterial agents and anticancer agent (5).

In view of the biological importance of 1,2 dithiole 3thione derivatives, it was planned to synthesize a new compounds linkage with fluoroquinolones and were evaluated for in vitro anticancer activity against 60 types of cancer cells.

\section{Materials and methods}

All the solvents and reagents used are of AR grade, Fluoroquinolones were purchase from China. The other chemicals were purchased from Sigma-Aldrich Chemical Company (Germany).

Melting points (mp) were determined in open capillaries, using Thomas melting point apparatus, expressed in ${ }^{0} \mathrm{C}$ and are uncorrected. The IR spectra of the compounds were recorded on Shimazu model WQF-510 FT-IR spectrometer using $\mathrm{KBr}$ disc.The $\mathrm{pH}$ of the solution were determined on $\mathrm{pH}$-meter.

\section{Biological Activity}

The biological activity of the compounds were tested against 60 types of cancer cell at National Cancer Institute (NCI), Development Therapeutic Program using One Dose Mean Graph,Maryland, USA.

\section{Synthesis of 5-(4-hydroxyphenyl)-1,2-dithiol-3- thione (1) 2}

A solution of $p$-hydroxyacetophenone $(0.04$ mole, $5.44 \mathrm{~g})$ in benzene $10 \mathrm{ml}$ was mixed with $(0.06$ mole, 4.56 $\mathrm{ml}$ ) of piperidine, then reflux under azeotropic condition for 10h. The reaction mixture was evaporated to dryness under reduced pressure. The crude product was dissolved in THF $5 \mathrm{ml}$, then add carbon disulfide $(0.06$ mole, $4.5 \mathrm{ml})$ was added dropwise and also a solution of sulfur $(0.19 \mathrm{~g})$ in THF $15 \mathrm{ml}$. The mixture was heated at $70{ }^{\circ} \mathrm{C}$ until the color of solution be red, then complete stirring at room temperature for $24 \mathrm{~h}$. The mixture was poured on ice-water $75 \mathrm{ml}$, then extract the product with dicholomethane. The organic layer was washed four times with water, then dried with sodium sulfate, filter then evaporate the solvent under reduced pressure give the compound (I). The melting point is (105$106{ }^{\circ} \mathrm{C}$ ), with $75 \%$ percentage yield. IR spectra show $\mathrm{v} \mathrm{cm}^{-1}$ 3437 (OH phenol), $2924(\mathrm{C}-\mathrm{H}), 1662(\mathrm{C}=\mathrm{C}), 1246(\mathrm{C}=\mathrm{S})$.

\section{Synthesis of fluoroquinolone ester derivatives (2- 4) ${ }^{2 \& 3}$}

To a solution of proper fluoroquinolone $(0.001 \mathrm{~mole})$ in pyridine $5 \mathrm{ml}$, thionyl chloride $(0.001$ mole $)$ was added dropwise in ice-bath. The resulted solution was refluxed for $1 \mathrm{~h}$., then poured on an ice-water $50 \mathrm{ml}$, neutralized with
$10 \%$ sodium bicarbonate to $\mathrm{pH}=8.5$. The solid crude product was washed with ice-water, filter and dried. These compounds were decomposed when the temperature was elevated to give high yields up to $86 \%$. The IR spectra (v, $\mathrm{cm}^{-1)} 3197$ for $(\mathrm{N}-\mathrm{H}), 2973-2933(\mathrm{C}-\mathrm{H}), 1711(\mathrm{C}=\mathrm{O}), 1626$ $(\mathrm{C}=\mathrm{C}), 1244(\mathrm{C}=\mathrm{S})$.

\section{Evaluation of the in Vitro Cancer Screen}

The human tumor cell lines of the cancer screening panel are grown in RPMI 1640 medium containing 5\% fetal bovine serum and $2 \mathrm{mM}$ L-glutamine. For a typical screening experiment, cells are inoculated into 96 well microtiter plates in $100 \mu \mathrm{L}$ at plating densities ranging from 5,000 to 40,000 cells/well depending on the doubling time of individual cell lines. After cell inoculation, the microtiter plates are incubated at $37^{\circ} \mathrm{C}, 5 \% \mathrm{CO}_{2}, 95 \%$ air and $100 \%$ relative humidity for $24 \mathrm{~h}$ prior to addition of experimental drugs (6).

After $24 \mathrm{~h}$, two plates of each cell line are fixed in situ with TCA, to represent a measurement of the cell population for each cell line at the time of drug addition (Tz). Experimental drugs are solubilized in dimethyl sulfoxide at 400 -fold the desired final maximum test concentration and stored frozen prior to use. At the time of drug addition, an aliquot of frozen concentrate is thawed and diluted to twice the desired final maximum test concentration with complete medium containing $50 \mu \mathrm{g} / \mathrm{ml}$ gentamicin. Additional four, 10 -fold or $1 / 2 \log$ serial dilutions are made to provide a total of five drug concentrations plus control. Aliquots of $100 \mu 1$ of these different drug dilutions are added to the appropriate microtiter wells already containing $100 \mu \mathrm{l}$ of medium, resulting in the required final drug concentrations (7).

Following drug addition, the plates are incubated for an additional $48 \mathrm{~h}$ at $37^{\circ} \mathrm{C}, 5 \% \mathrm{CO} 2,95 \%$ air, and $100 \%$ relative humidity. For adherent cells, the assay is terminated by the addition of cold TCA. Cells are fixed in situ by the gentle addition of $50 \mu 1$ of cold $50 \%(\mathrm{w} / \mathrm{v}) \mathrm{TCA}$ (final concentration, $10 \% \mathrm{TCA}$ ) and incubated for 60 minutes at $4^{\circ} \mathrm{C}$. The supernatant is discarded, and the plates are washed five times with tap water and air dried. Sulforhodamine B (SRB) solution $(100 \mu \mathrm{l})$ at $0.4 \%(\mathrm{w} / \mathrm{v})$ in $1 \%$ acetic acid is added to each well, and plates are incubated for 10 minutes at room temperature. After staining, unbound dye is removed by washing five times with $1 \%$ acetic acid and the plates are air dried. Bound stain is subsequently solubilized with $10 \mathrm{mM}$ trizma base, and the absorbance is read on an automated plate reader at a wavelength of $515 \mathrm{~nm}$. For suspension cells, the methodology is the same except that the assay is terminated by fixing settled cells at the bottom of the wells by gently adding $50 \mu \mathrm{l}$ of $80 \%$ TCA (final concentration, $16 \%$ TCA). Using the seven absorbance measurements [time zero, $(\mathrm{Tz})$, control growth, $(\mathrm{C})$, and test growth in the 
presence of drug at the five concentration levels (Ti)], the percentage growth is calculated at each of the drug concentrations levels. Percentage growth inhibition is calculated as (8):

$[(\mathrm{Ti}-\mathrm{Tz}) /(\mathrm{C}-\mathrm{Tz})] \times 100$ for concentrations for which $\mathrm{Ti}>/=\mathrm{Tz}$

$[(\mathrm{Ti}-\mathrm{Tz}) / \mathrm{Tz}]$ x 100 for concentrations for which $\mathrm{Ti}<\mathrm{Tz}$.

Three dose response parameters are calculated for each experimental agent. Growth inhibition of $50 \%$ (GI50) is calculated from $[(\mathrm{Ti}-\mathrm{Tz}) /(\mathrm{C}-\mathrm{Tz})] \times 100=50$, which is the drug concentration resulting in a $50 \%$ reduction in the net protein increase (as measured by SRB staining) in control cells during the drug incubation. The drug concentration resulting in total growth inhibition (TGI) is calculated from $\mathrm{Ti}=\mathrm{Tz}$. The LC50 (concentration of drug resulting in a $50 \%$ reduction in the measured protein at the end of the drug treatment as compared to that at the beginning) indicating a net loss of cells following treatment is calculated from $[(\mathrm{Ti}-\mathrm{Tz}) / \mathrm{Tz}]$ x $100=-50$. Values are calculated for each of these three parameters if the level of activity is reached; however, if the effect is not reached or is exceeded, the value for that parameter is expressed as greater or less than the maximum or minimum concentration tested

NCI60 testing is performed in two parts: first a single concentration is tested in all 60 cell lines at a single dose of $10^{-5}$ molar or $15 \mu \mathrm{g} / \mathrm{ml}$. If the results obtained meet selection criteria, then the compound is tested again in all 60 cell lines in $5 \times 10$ fold dilutions with the top dose being $10-4$ molar or $150 \mu \mathrm{g} / \mathrm{ml}$. Compounds accepted for NCI60 testing are prepared for both 1-dose and 5-dose testing at the same time (9).

Synthetic agents for the Cancer screen with a known molecular weight are prepared in DMSO:glycerol 9:1 (unless otherwise noted) at a concentration of $4 \mathrm{mM}$ for the one dose assay and $40 \mathrm{mM}$ for the 5-dose assay. In both cases the solution is diluted 1:400, giving a High Test concentration of 10 or $100 \mu \mathrm{M}$ respectively. Synthetic agents (macromolecules) without a molecular weight are prepared in DMSO:glycerol 9:1 (unless otherwise noted) at a concentration of 6 and $60 \mathrm{mg} / \mathrm{ml}$ which is diluted 1:400, giving a High Test concentration of 15 and $150 \mu \mathrm{g} / \mathrm{ml}$.

The Cancer screen requires $100 \mu \mathrm{l}$ for $1 \log$, 5-dose dilutions of regular compounds and $75 \mu 1$ for 1-dose testing. 1 -dose testing is done at $1 / 10$ th the high concentration of 5 dose testing, so the volume requirement is $210 \mu \mathrm{l}+20 \%$ at $40 \mathrm{mM}$ for compounds with molecular weights or $210 \mu \mathrm{l}+$ $20 \%$ at $60,000 \mu \mathrm{g} / \mathrm{ml}=250 \mu \mathrm{l}$ for compounds without molecular weights (macromolecules) (i.e. less than $10 \mathrm{mg}$ for $\mathrm{MW}=1000$ or $15 \mathrm{mg}$ for compounds tested as weight/volume).
Compounds that are identified as needing to be prepared fresh before use are solubilized no more than one hour before serial dilution. It is serial diluted on a TECAN Freedom 200 (two drugs/plate), transferred to a column plate and stored under nitrogen in a desiccator box until delivered to the testing lab.

For 1-dose 60 cell testing: On the day of or the day before drug addition to growing cells in tissue culture, a strip of standards (adriamycin, NSC 123127 prepared and stored the same as the compounds) is added to the detachable well plate, and $90 \mu 1$ DMSO is added to each well (4 mM solution), and mixed/sonicated and $75 \mu \mathrm{l}$ is transferred, using a 12 channel hand pipettor, to a 12 channel reservoir plates (column plates), which is sealed and stored under nitrogen in a desiccator box until delivered to testing lab. The labels are placed at the right and the left of the front of the reservoir plate. It will be the first and the last NSC number in the row. Rows are transferred from detachable plate to columns 3-12 of column plates. Plates are sealed and stored under nitrogen no more than 24 hours prior to drug addition (10).

\section{Results and Discussion}

In the present study, three compounds were synthesized as depicted in (scheme 1) in two steps. Firstly, the compound (I) (5-(4-hydroxyphenyl)- 1,2 dithiol-3 thione) was prepared in a high yield via condensation of the 4hydroxyl acetophenone with piperdine to form an intermediate (I), then react with mixture of $\mathrm{CS}_{2}$ and Sulfur.

Secondly, the condensation of the dithio-3-thione compound (II) with the proper fluoroquinolones (Ciprofloxacin NSC $=760553$, Getafloxacin NSC $=760554$, Moxifloxacin NSC $=760555)$ to give compounds $(2,3 \& 4)$ respectively as shown in scheme 1 .

The anti-infective agents are fight cancer cells. The evaluation of in vitro anti cancer activity against 60 types of cancer cell lines (10). The vehicles of choice are DMSO and water. The three agents are solubilized using one of these two vehicles. Other vehicles are used at the request of the supplier or based upon past testing methods. Agents utilizing volatile solvents as a vehicle are labeled 'Fresh' and are prepared within an hour of screening addition. Currently, all synthetic agents for Prescreen/Cancer screening are prepared in DMSO:glycerol 9:1, unless another vehicle is indicated. When water is indicated, the compound is solubilized in either distilled water or in cell culture media (RPMI 1640) without serum. All solubilizations requiring THF, Ethanol, Methanol, or other volatile solvents are prepared fresh to reduce evaporation $(8,9)$.

The goal of solubilization is to deliver the highest requested concentration of an agent for the screening process. However, the number of vials required by the 
program screening the agent determines the minimum amount of vehicle that can be added. For the cancer screening lab, if the amount of material sent is insufficient to create the required number of aliquots, the concentration must be dropped to ensure an appropriate volume is met. If it is a retest compound, permission must be obtained prior to dropping the concentration.

The compound $2(\mathrm{NSC}=760553)$ show anti cancer activity against renal cell (type 786.0 ) about $47.85 \%$, while the compound $4(\mathrm{NSC}=760555)$ show activity against three types of cancer cells (Leukemia CCRF-CEM, Melanoma LOX. IMVI, and Renal UO-31) the activities are 78.57, 77.83 and 77.53$) \%$ respectively. All activities against cancer cell in vitro are low, further studies are needed to enhance activity (11).

The expected mechanism is due to sulfhydral group (SH) act as source for $\mathrm{H}_{2} \mathrm{~S}$ gas which plays an important role gastransmitter in the biological cells, and the effect of the third generation antibacterial fluoroquinolones that inhibit DNA grase will increase the inhibition of the tumor.<smiles>CC(=O)c1ccc(O)cc1</smiles><smiles>C1CCNCC1</smiles><smiles>C=C(c1ccc(C)cc1)N1CCCCC1</smiles><smiles>Oc1ccc(-c2cssc2=S)cc1</smiles>

1,2dithiol, 3 thione $4^{-}$phenol compound (I)<smiles>[R]OC(=O)OC(C)=C1CC1n1cc(C)c(=O)c2cc(F)c(N3CCNCC3)cc21</smiles>

Scheme 1: Synthesis of 1,2dithiol 3 -thione 4 - fluoroquinolone ester derivatives 
Iraqi Journal of Veterinary Sciences, Vol. 26, Supplement IV, 2012 (115-121)

Proceedings of the $6^{\text {th }}$ Scientific Conference, College of Veterinary Medicine, University of Mosul

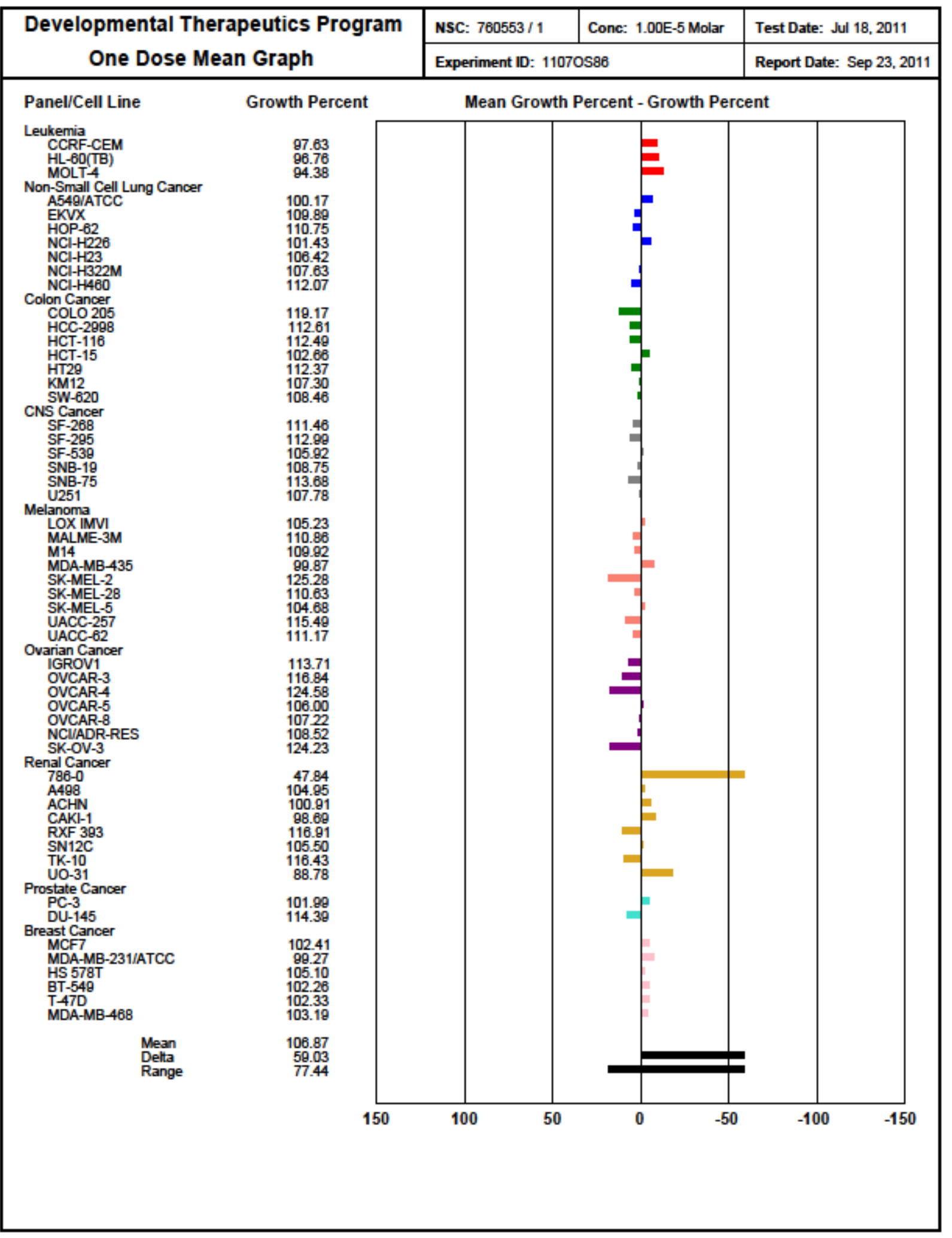

Figure 1: The Screening test of compound 2 against 60 cancer cells in vitro. 
Iraqi Journal of Veterinary Sciences, Vol. 26, Supplement IV, 2012 (115-121)

Proceedings of the $6^{\text {th }}$ Scientific Conference, College of Veterinary Medicine, University of Mosul

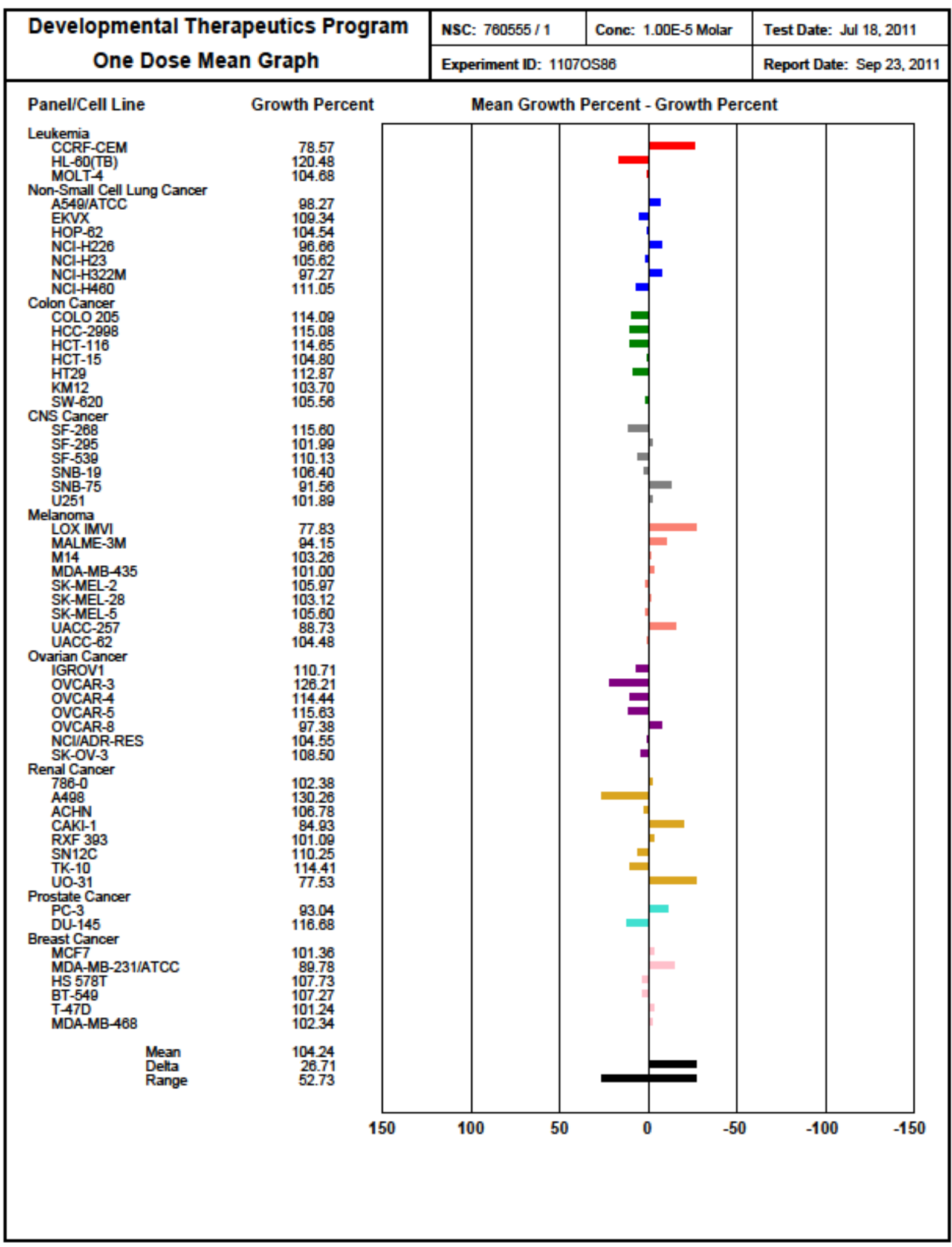

Figure 2 : The Screening test of compound 4 against 60 cancer cells in vitro. 


\section{Acknowledgments}

The authors are thanks National Cancer Institute (NCI), Maryland, USA., for analyzing and testing our new compounds.

\section{References}

1. Roebuck BD, Thomas JC, Yuan Li, KarenJB, Sridev B., Jian Yan, Stephen JG, Thomas WK and Thmoas RS. (2003). Evaluation of the cancer chemoprotective potency of dithiole thione analogs of Oltipraz.Carcinogenesis 24 (12), 1919-1928.

2. Young Youn, Ha-Jin Lee, Sung Keon N., Jongki H.and Dong-Youn Noh.(2000). Synthesis and characterization of two different 1,3dithiole-2-thiones as precursors of TTF donor molecule. J. of Korian Chemical Society., 44, 513-517.

3. Wang YZ, Xian M. Cysteine activated hydrogen sulfide $\left(\mathrm{H}_{2} \mathrm{~S}\right)$ donors.(2011) J. Am. Chem. Soc., 133, 15-17.

4. Fiorucci S., Orlandi S., Mencarelli A., Calend G., Santagad V. Distrutti E.,(2007). Santucciivity of a hydrogen sulphide - releasing derivative of mesalamine (ATB-429) in a mouse model of colitis. British j. Pharm., 155, 994-1002.
5. Trawneh Sa, Zahra JA,Kamal MR, El-Abadelah MM, Zani F,Incerti M,Cavazzoni A,Alfleri RR,Petronini PG and Vicini P.(2010). Synthesis and biological evaluation of tetracyclic fluoroquinolones as antibacterial and anti cancer agents.Bioorg.Med. Chem.18(16): 58735884.

6. Alley, M.C., Scudiero, D.A., Monks, P.A., Hursey, M. L., Czerwinski, M.J., Fine, D.L., Abbott, B.J., Mayo, J.G., Shoemaker, R.H., and Boyd, M.R.(1988). Feasibility of Drug Screening with Panels of Human Tumor Cell Lines Using a Microculture Tetrazolium Assay. Cancer Research 48: 589-601.

7. Grever, M.R., Schepartz, S.A., and Chabner, B.A.(1992). The National Cancer Institute: Cancer Drug Discovery and Development Program. Seminars in Oncology, 19, (6), 622-638..

8. Boyd, M.R., and Paull, K.D.(1995). Some Practical Considerations and Applications of the National Cancer Institute In Vitro Anticancer Drug Discovery Screen. Drug Development Research 34: 91-109.

9. Shoemaker, R. H.(2006). The NCI60 Human Tumor Cell line Anticancer Drug Screen. Nature Reviews, 6: 813-823.

10. Roschke AV, Tonon G, Gehlhaus KS, McTyre N, Bussey KJ, Lababidi S, Scudiero DA, Weinstein JN, Kirsch IR.(2003). Karyotypic complexity of the NCI-60 drug-screening panel Cancer Res. 15;63(24):8634-47.

11. Lorenzi PL, Reinhold WC, Varma S, Hutchinson AA, Pommier Y, Chanock SJ, Weinstein JN.(2009). DNA fingerprinting of the NCI-60 cell line panel. Mol Cancer Ther. 8(4):713-24. 